\title{
ON THE JUDGMENT OF HISTORY
}

RUTH BENEDICT BOOK SERIES 


\section{RUTH BENEDICT BOOK SERIES \\ Edited by David Scott and Elizabeth A. Povinelli}

With Series Committee Members Nadia Abu El-Haj, Vanessa Agard-Jones,

Zoe Crossland, Maria José de Abreu, and Naor Ben-Yehoyada

Named after one of the founders of American anthropology and the Columbia Department of Anthropology, the Ruth Benedict Book Series is inspired by Benedict's passionate engagement with the critical political, aesthetic, and theoretical problems of the twentieth century but places them in the global conditions of the twenty-first. Contributions to the series explore contemporary critical thought in politics and aesthetics through a deep knowledge of the global condition in specific localities and regions. The scope of the series is capaciously theoretical and determinately international with special emphasis on settlercolonial, postcolonial, and capitalist regimes. The books present crisp interventions in a multiplicity of disciplines, but are also statements whose reckoning cuts across the critical humanistic and social sciences.

Secular Translations: Nation-State, Modern Self, and Calculative Reason, Talal Asad I Am the People: Reflections on Popular Sovereignty Today, Partha Chatterjee 


\section{ON THE \\ JUDGMENT OF \\ HISTORY}

JOAN WALLACH SCOTT 


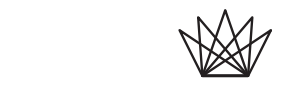

\author{
COLUMBIA UNIVERSITY PRESS \\ Publishers Since 1893 \\ New York Chichester, West Sussex \\ cup.columbia.edu
}

Copyright $\odot 2020$ Columbia University Press

All rights reserved

Library of Congress Cataloging-in-Publication Data

Names: Scott, Joan Wallach, author.|Scott, Joan Wallach.

In the name of history.

Title: On the judgment of history/Joan Wallach Scott.

Description: New York : Columbia University Press, 2020.| Series: Ruth

Benedict book series | See also: In the name of history by Joan Wallach Scott.

| Includes bibliographical references and index.

Identifiers: LCCN 2020004401 (print) | LCCN 2020004402 (ebook) |

ISBN 9780231196949 (cloth) | ISBN 9780231196956 (paperback) |

ISBN 9780231551908 (ebook)

Subjects: LCSH: History-Philosophy. | Historiography. | Nationalism-

History. | Racism-History. | Nuremberg Trial of Major German War

Criminals, Nuremberg, Germany, I945-1946-History. | South Africa.

Truth and Reconciliation Commission-History. | Reparations for

historical injustices - United States-History.

Classification: LCC Di6.9 .S427 2020 (print) | LCC Di6.9 (ebook) |

DDC $90 \mathrm{O}-\mathrm{dc} 23$

LC record available at https://ccn.loc.gov/202000440I

LC ebook record available at https://ccn.loc.gov/2020004402

Columbia University Press books are printed on permanent and durable acid-free paper.

Printed in the United States of America

Cover design: Chang Jae Lee 
But whatever this new understanding of the past holds to be irrelevant-shards created by the selection of materials, remainders left aside by an explication - comes back, despite everything, on the edge of discourse or in its rifts and crannies; "resistances," "survivals," or delays discretely perturb the pretty order of a line of "progress" or a system of interpretation.

- Michel de Certeau, The Writing of History 
